\title{
Enamel Conditioning Effect on Hybridisation of Resin Modiffied Glass lonomer-Based into Preventive Sealing
}

\begin{abstract}
CATALINA IULIA SAVEANU1', DANIELA ANISTOROAEI*, ALEXANDRA ECATERINA SAVEANU'*, OANA DRAGOS², LOREDANA GOLOVCENCU ${ }^{1}$

${ }^{1}$ Grigore T. Popa University of Medicine and Pharmacy, Faculty of Dental Medicine, 16 Universitatii Str., 700115, Iasi, Romania ${ }^{2}$ National Institute of Research-Development for Technical Physics - IFT Iasi, 113 Tudor Vladimirescu Blvd., 700870, Iasi, Romania

Disadvantages of diacrilic composite resins and glass ionomers cements have stimulated research to develop hybrid materials to eliminate the downsides and take advantage of their benefits. The purpose of this study was three-dimensional analysis of a flux material with a resin-modified glass ionomer (RMGI) cement in preventive sealing by two techniques of enamel substrate approach, respectively, with acidic conditioning with $37 \%$ orthophosphoric acid and free. The best results were observed in the RMGI when no substrate conditioning was performed.
\end{abstract}

Key words: microleakage, sealant, resin composite, primary prevention

Disadvantages of diacrilic composite resins and glass ionomers cements have stimulated research to develop hybrid materials to eliminate the downsides and take advantage of their benefits. Subsequent studies led to two new classes of materials: resin-modified ionomeric cements, which are located closer to ionomeric glass cements, and compounds that are closer to the diacrilic composite resins [1].

McCabe classifies the hybrids materials in two categories in 1998 [2,3]; modified composites and resinmodified glass ionomer cements. Resin-modified glass ionomeric cements are a category of materials for use in preventive dentistry. Thus, the first materials used were developed in 1960 in the Laboratory of the Gouvernment Chemist, London [4], in an attempt to obtain an adhesive and physiognomic obturation material acceptable for the repair of coronary tooth lesions of the frontal teeth. In 1988, Wilson and McLean [5,6] and subsequently recovered at Mount G] in 2002 [7] made a reference classification of glass ionomer cements in three types, Type I - Cement Type II - Restorative Cements and Type III - Base and fissure sealer, Type IV -core build-up.

The advantages of these materials used in the primary prevention of dental caries are that they release fluorides with a cariostatic effect, are biocompatible, have low thermal conductivity, have radioactivity, optimal adhesion, good dimensional stability.

The main properties that offer uses are biological properties, biocompatibility and cariostatic effect by releasing fluoride ions (and the possibility of fluorine recharge by fluoride in the oral cavity, [8-10] preventing secondary caries [11-14]. The chemical properties are given by ions exchange adhesions, eliminating completely the micro cracks, the material acting as a fluoride reservoir. The erosion of the material is influenced by the composition of the cement, the time elapsed from the preparation, the oral environment, the contraction of the polymerization which is higher than the conventional $\mathrm{CIS}$ is an unfavorable factor. Rheology of these injection materials recommends them, thus ensuring perfect fit and sealing. Compared to conventional CIS, it has reduced downtime, low initial acidity with rapid $\mathrm{pH}$ increase, higher wear resistance, lower sensitivity to moisture, lower solubility than $\mathrm{CIS}$, superior aesthetics.

The mechanical properties of compressive strength, elasticity, abrasion resistance more favorable than CIS are an additional asset in recommending these materials.

Clinical studies of CIMR behavior have shown good adherence to the dental structure [15-23].

Other studies have show $n$ that remineralization can be potentiated by CIS [24-27].

Keeping a dry operatoaire field is an essential condition for the durability of adhesion of a material over time. When clinical conditions do not allow for perfect isolation, it is advisable to use a hybrid or conventional material. Due to the deficiency of the chemical, mechanical, rheological, physiological properties of conventional materials, the use of CIMR can reduce certain inconveniences. Since the achievement of $37 \%$ orthophosphoric acid conditioning in the enamel structure is an optional step, the material presenting predominantly a chemical adhesion mechanism, we have questioned whether this is sufficient for a good adhesion of the sealant. Specialty studies performed on the ionomer glass fill indicate that this conditioning will improve adhesion. Also sealing materials to favor a good wetting of the substrate should be as little as filler. This in turn does not provide a wear resistance of the material. The use of a micro-filled liner can prolong the durability of the seal to increase the wear resistance. The purpose of this study was three-dimensional analysis of a flux material with a resin-modified ionomer cement structure and complexion of modified ion-glass resin material in preventive sealing by two techniques of enamel substrate approach, respectively, with acidic conditioning with $37 \%$ orthophosphoric acid and free. The null hypothesis consists in the fact that there is no difference in the complexification of the material in the enamel substructure when the acidic orthophosphoric acid grafting is $37 \%$ and when not. The testable hypothesis is that it is established that there are differences in the complexity of the material in the enamel substructure when the acidic orthophosphoric acid grafting is 37\% and when not.

*email: cmiortodent@yahoo.com, Phone:+40721377269; alexandrasaveanu@yahoo.com, Phone: +40755 569120 


\section{Experimental part}

The material was analyzed as structure and as surface properties.

For AFM analysis, samples of lonofeel F (Schultzer) were prepared. The materials were applied according to the manufacturer's instructions between two cellulosic matrices (No. 437 Alfred Becht GmbH-D 7600 Offenburg, Germany) and then between two glass plates to obtain a flat surface. Samples were polymerized by photoactivation for 40 seconds with halogen lamp (QTH), $570 \mathrm{~mW} / \mathrm{cm}^{2}$ (3MESPE). After the polymerization, the materials were removed and analyzed. Nebulosity and surface topography was analyzed by AFM (Park Systems XE -100). AFM analysis was performed using a single silicon crystal $(<10$ $\mathrm{nm})$, which was connected to the substrate with the console. The images were processed at a scan rate of 0.5 $\mathrm{Hz}$ and a resolution of $256 \times 256$ pixels. For each specimen, $5 \mu \mathrm{m} \times 5 \mu \mathrm{m}$ was scanned. Three-dimensional topographic analysis was performed by XEI-Image Processing and Analysis. The hardness of the roughness a was measured in nanometers.

Sample analysis with electronic scanning microscopy SEM

For the SEM analysis, samples of Ionofeel F (Schultzer) were prepared. The materials were applied according to the manufacturer's instructions. Most were polymerized by 40 second light-activated photoactivation with halogen lamp (QTH), power $570 \mathrm{~mW} / \mathrm{cm}^{2}$ (3MESPE). The microstructure of the materials was analyzed by SEM (JEOLJ SM 6390 Japan).

Studyanalysis of interface Sealant-enamel by SEM analysis of interface Sealant-Enamel

The study was conducted in vitro on premolar and molar human teeth extracted for orthodontic or periodontal reasons. The evidence was studied by obtaining informed patient consent and the opinion of the Ethics Committee of the University of Medicine and Pharmacy Gr.T.Popa, lasi. The samples were randomly divided into 2 equal $(\mathrm{Gr})$ groups and were sealed as follows: GR. 1= lonofeel $F$ (Schultzer), acid conditioning adhesive system;GR. 2= lonofeel F (Schultzer), without acidic conditioning, adhesive system;

The teeth were sealed using the adhesive system of $3 \mathrm{M}^{\mathrm{TM}}$ Schotchbond Etch, Meta Bond 2 (Metabiomed). The seals were made in accordance with the manufacturer's instructions. Samples were photographed with halogen lamp (3M), stored in physiological serum for maximum (48h), longitudinally sectioned, diamond-shaped, finished, conditioned (H3P04-37\%-5s). Measurement of the size of the hybrid layer was performed in three points for each face of each tooth, resulting in 12 measurements for each material.

\section{Results and discussions}

Analysis of the sealing of the sealing materials highlighted the fact that they adhere to the enamel substrate. The best adhesion was obtained in the case of lonofeel without acidic conditioning 5.34 $\mu \mathrm{m}( \pm 2.46)$ (table 1, 2).

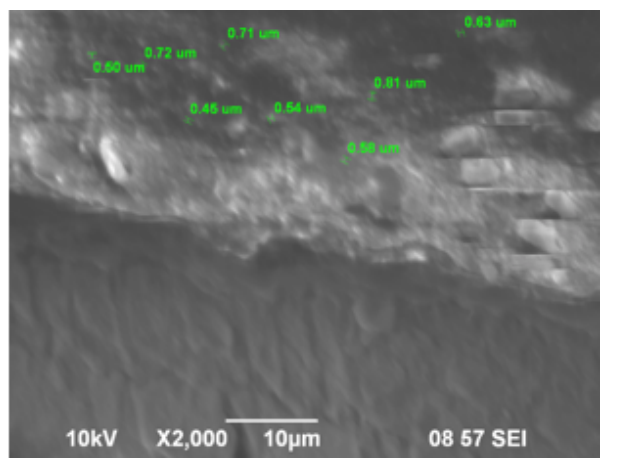

Fig.1 .SEM aspect of particle micromorfology of a sealant resn modiffied glass ionomer lonofeel $F$ (Schultzer)

\begin{tabular}{|l|r|r|r|r|r|}
\hline & \multicolumn{1}{|c|}{ N } & \multicolumn{1}{c|}{ Minimum } & Maximum & \multicolumn{1}{c|}{ Mean } & \multicolumn{1}{c|}{ Std. Deviation } \\
\hline Ionofeel without & 12 & 2.33 & 9.03 & 5.3400 & 2.46963 \\
H3PO4-37\% & 12 & 1.83 & 6.25 & 3.4542 & 1.37416 \\
\hline $\begin{array}{l}\text { Ionofeel H3PO4- } \\
37 \%\end{array}$ & 12 & & & & \\
\hline Valid N (listwise) & & & & & \\
\hline
\end{tabular}

Tabel 1

DESCRIPTIVE STATISTICS

Correlations

\begin{tabular}{|c|c|c|c|}
\hline & & $\begin{array}{c}\text { Ionofeel without } \\
\text { H3PO4-37\% }\end{array}$ & $\begin{array}{c}\text { Ionofeel with H3PO4- } \\
\qquad 37 \%\end{array}$ \\
\hline \multirow{4}{*}{$\begin{array}{l}\text { Ionofeel without } \\
\text { H3PO4-37\% }\end{array}$} & Pearson Correlation & & \\
\hline & & 1 & .456 \\
\hline & Sig. (2-tailed) & & .136 \\
\hline & $\mathrm{N}$ & 12 & 12 \\
\hline \multirow{4}{*}{$\begin{array}{l}\text { Ionofeel with } \\
\text { H3PO4-37\% }\end{array}$} & Pearson Correlation & & \\
\hline & & .456 & 1 \\
\hline & Sig. (2-tailed) & .136 & \\
\hline & $\mathrm{N}$ & 12 & 12 \\
\hline
\end{tabular}

3* Correlation is significant at the 0.01 level (2-tailed).

* Correlation is significant at the 0.05 level (2-tailed).

Tabel 2

CORRELATIONS BETWEEN GROUPS 

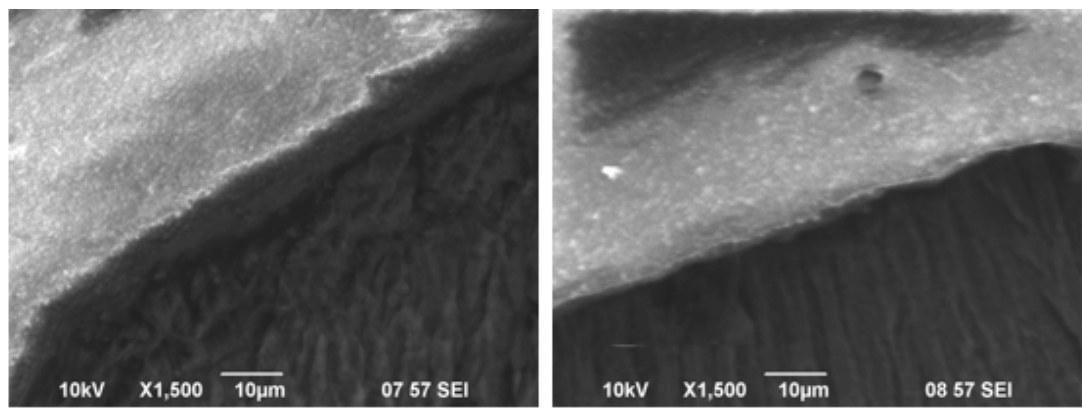

Table 3

SURFACE ROUGHNESS ANALYSIS Ra [nm] FOR 5 $\mu \mathrm{m}$ THROUGH AFM IMAGES.

\begin{tabular}{|c|c|c|c|c|c|}
\hline Material & Manufacturer & Caracteristics & $\mu \mathrm{m}$ & Ra [nm] & Rz(nm) \\
\hline Ionofeel & Schultzer RL & Resin modiffied glass & 5 & 6.66 & 119.87 \\
& Superior $\mathrm{GmbH}$, & ionomer & & & \\
& Hamburg/Germany & LOT 5210545 & & & \\
& & CE0482 & & & \\
& & & & & \\
& & & &
\end{tabular}
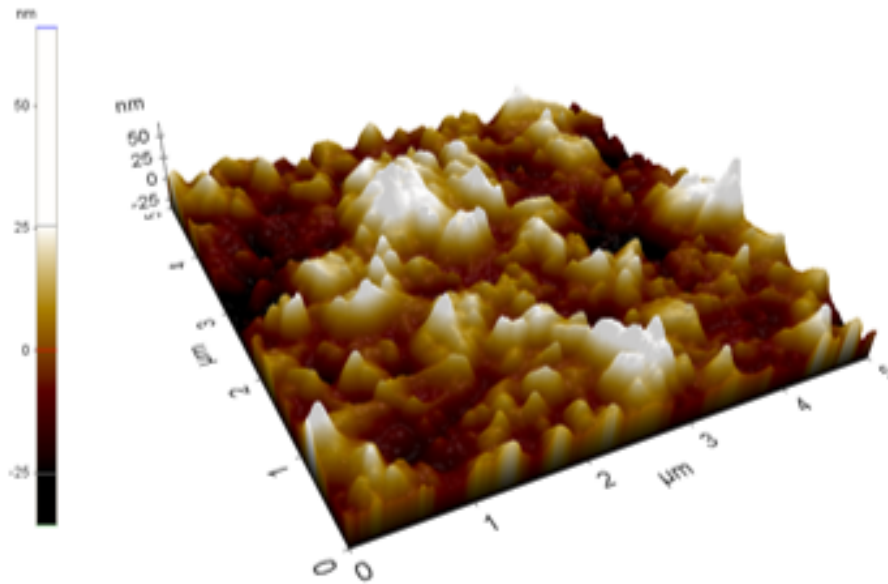

AFM analysis

The assessment of the roughness of the sealing material flow revealed that the degree of roughness varies according to the area of study. Ionofeel $F$ (Schultzer) material is presented for a $5 \mu \mathrm{m}$ ruggedness range of $\mathrm{Rz}(\mathrm{nm})$ of 119.87. (table 3)

Analysis of the hybrid layer size in two studied groups did not reveal statistically significant differences $p=0.456$, with an average of $5.34 \mu \mathrm{m}( \pm 2.46)$ for the lonofeel sealed group without acidic conditioning. This can be explained bythe mineral support in the tooth structure that establishes several connections with ionomer glasses than when demineralizing the substrate. On the other hand, the results for the 3.50um ( \pm 1.37 ) lonofeel glass ionomer resin results are similar to those obtained in other studies for composite resin without filling. Fotoseal $3.36 \mu \mathrm{m}( \pm 1.02)$, Permaseal $3.45 \mu \mathrm{m}( \pm 1.19)$, Nanofil 3.13um ( \pm 076$)$. Similar studies show the sealing of the seal on a depth between 16 and 23um [28,29].

The purpose of the acid scrambling is to create microretention in the form of crypts [27] by the partial and preferential dissolution of prismatic and interprismatic mineral crystals [30] with the appearance of microtags and macrotags, the increase of the enamel surface free energy, which facilitates wetting of the area engraved [31,32], providing a larger contact surface between enamel and material $[33,34]$. However, obtaining efficient enamel hybridization by maximum infiltration is dependent on the orientation of the crystals relative to the surface thus
Fig. 2 (left) and fi. 3 (right). SEM maginifiation $X$ 1500 of the enamel interface - modified ionomer glass Ionomer F (Schultzer) - without H3PO4-37\% and with $\mathrm{H} 3 \mathrm{PO}$ - $-37 \%$ conditioned. Optimal microretentive reliefs (type I) are obtained only when the enamel has been conditioned in a direction as parallel to the prism axis, the acid attack perpendicular to it, sometimes proving to be ineffective. This may also be the reason why there was no better infiltration of samples treated with orthophosphoric acid. Therefore, in most cases, enameling is recommended if the enamel is used to condense.

In other situations, the maximum demineralization is in peripheral interprismatic areas with the center of the prism integral [35]. Also, in cases where both types of demineralization coexist, an irregular amorphous relief is obtained after conditioning with $37 \%$ orthophosphoric acid for 15 seconds [35,36].

For young people, where the interprismatic organic substance is more resistant to acid attack, it is well represented, like enamel rich in acid-resistant fluorapatite crystals, the relief obtained after conditioning acid will be less retentive and irregular. [35-37].

Glass ionomeric hybrids can adhere by the same mechanism as conventional glass ionomers, but their composition offers the possibility of adhering through similar resins. Adhesion can be improved if enamel and / or dentin are etched or conditioned. Most manufacturers recommend the use of a conditioning agent like an aqueous solution of polyacrylic acid. Other manufacturers indicate prior to material insertion, conditioning and then applying a primer to enamel surfaces. The primer may be 
a modified polyacid solution with methacrylic groups (one of the basic ingredients of RMGI) capable of partially demineralizing the surface of dental hard tissues and increasing their wettability.

The measured value of adhesive strength is higher for hybrid materials and depends on enamel treatment and polymerization conditions [33]. Compared to conventional glass ionomers, the strength of the hybrid glass ionomer (FUJI II LC) adhesion is $17.4 \mathrm{MPa}$, when the enamel is etched with $10 \%$ polyacrylic acid, and when engraved with orthophosphoric acid, the adhesion strength of $20.5 \mathrm{MPa}$ [33]. Some RMGI class products have an inherentadhesion to enamel and dentin by a mechanism similar to CIS, with free $\mathrm{COOH}$ being able to interact with the mineral substrate of the tooth. Clinical study shows that due to the resin sealing material present tightness and maintains its properties between 3 and 6 months and after 12 months some changes occur like coloration, marginal gap or even carious lesions [38].

\section{Conclusions}

The best material imbrication was observed in the modified ionomer glass ionomer resin when no substrate conditioning was performed.

Within the limits of this study, we can state that the modified glass-ionomer resin of the liner type used for sealing exhibits a very good complication without the conditioning of the substrate. Thus, the working time will be reduced to a minimum, showing a very good indication in situations where a dry field operator cannot be obtained, there is an increased cariogenic risk and the working time has to be reduced to a minimum.

Acknowledgments: A part of this study was supported by the CNCSIS grant budget, no.2669/2008 - 2011 ideas competition-exploratory research projects.

\section{References}

1.Mc CABE J.F. WALLSW.G. Applied Dental Materials, $8^{\text {th }}$ ed., Blackwell Science, London, UK, 1998

2.MC CABE J.F. Applied Dental Materials, 7th ed., Blackwell Science, London, UK, 1994

3.WILSON A.D., KENT B.E., A new translucent cement for dentistry. The glass ionomer cement, Brit.Dent.J ., 132, 133, (1972).

4.WILSON AD, MC LEAN, Glass ionomer cement Chicago:Quintessence 1998.

5.WILSON AD, MCLEAN JW (1988), The setting reaction and its clinical consequences In: Glass ionomer cement, Chapter 3, Chicago, IL: Quintesence Publishing Co.,Inc.,pp.43-56.

6.MOUNT GJ , An atlas of glass-ionomer cements. A clinical's guide 3rd edn, London: Martin Dunitz Ltd, 2002.

7.GAO W, SMALES RJ, GALE MS., Fluoride release/uptake from newer glass-ionomer cements used with the ART approach, Am J Dent 2000;13:201-204.

8.PATRASCU I., Materiale dentare-Editura Horanda Press 2002, Bucure- - sti.

9.ROTHWELL M, ANSTICE HM, PEARSON GJ. The uptake an release of fluoride by ion-leaching cements after exposure to toothpaste. J Dent 1998; 26:591-597.

10.HERRERA M, CASTILLO A, BACA P., CARRION P, Antibacterial activity of glass ionomer restorative cements exposed to cavity - producing microorganisms, Oper Dent 1999;24:286-291.

11.GIUROIU, CRISTIAN LEVENTE; CARUNTU, IRINA-DRAGA; LOZNEANU, LUDMILA; ET AL Dental Pulp: Correspondences and Contradictions between Clinical and Histological Diagnosis . Biomed Research International Article Number: 960321 Published: 2015 12.HERRERA M, CASTILLO A, BRAVO M, LIEBANA J, CARRION P, Antibacterial activity of resin adhesives, glass ionomer and resin modified glass ionomer cements and a compomer in contact with caries samples, Oper Dent 2000;25:265-269. 566
13.GILMOUR AS, EDMUNDSDH, NEWCOMBE RG, Prevalence and depth of artificial caries-like lesions adjacent to cavities prepared in roots and restored with a glass ionomer or a dentin-bonded composite material, J Dent Res 1997; 76:1854-1861.

14.BRACKETT MG, DIB A, BRACKETT WW., ESTRADA BE., REYES AA., One-year clinical performance of a resin composite restorative material in unprepared Class V restorations, Oper Dent 2002;27:112116

15.BRACKETT WW, COVEY DA, ST GERMAIN HA JR, One-year clinical performance of a self-etching adhesive in a class $V$ resin composites cured by two methods, Oper Dent 2002;27:218-222.

16.AZZOPARDI A, BARTLETT DW, WARSON TF, SHERRIFF M., The measurement and prevention of erosion and abrasion J Dent 2001;29:395-400.

17.FOLWACZNY M, LOHER C, MEHL A, KUNZELMANN KH, HINKEL R., Tooth-colored filling materials for the restoration of cervical lesions: A 24-month follow-up study, Oper Dent 2000;25:251-258.

18.TYAS MJ, BURROW MF, Clinical evaluation of a resin- modified glass ionomer adhesive system: Results at five years, Oper Dent 2002;27:438-441.

19.TYAS MJ, MF BURROW, Adhesive restorative materials: A review, Australian Dental J ournal 2004;4(3):112-121.

20.SAVAS S, COLGECEN O, YASA B, KUCUKYILMAZ E.Color stability, roughness, and water sorption/solubility of glass ionomer-Based restorative materials. Niger J Clin Pract. 2019 Jun;22(6):824-832. doi: 10.4103/njcp.njcp_592_18.

21.*** Use of Pit-and-Fissure Sealants Pediatr Dent. 2017 Sep 15;39(6):156-172.

22.PAPAGEORGIOU SN, DIMITRAKI D, KOTSANOS N, BEKES K, VAN WAES H.Performance of pit and fissure sealants according to tooth characteristics: A systematic review and meta-analysis. J Dent. 2017 Nov;66:8-17. doi: 10.1016/j.jdent.2017.08.004. Epub 2017 Aug 8.

23.ALVES M.L., JB. BRANDAO PR., Atraumatic restorative treatments:clinical, ultrastructural and chemical analysis, Caries Res 2002;36:430-436.

24.GARCIA-GODOY F, New development in oral care technology Am J Dent 2002;15:2A (Editorial).

25.NGO, H, Biological properties of glass-ionomers. In:Mount GJ ed. An atlas of glass-ionomer cements. A clinician's guide. London: Martin Dunity, 2002:43-55.

26.NGO, H, MOUNT GJ , PETERS MCRB, (1997), A study of glass ionomer cement and its interface with the enamel and dentin using a lowtemperature, high resolution scanning electron microscope technique, Quintesence International 28; 63-69.

27.NAKABAYASHI N, PASHLEY DH TOKYO, Hybridization of dental hard tissue Quintessence International, 1998;].

28.SAVEANU CI., TODIRASCU A, MAFTEI I., DANILA I. The influence of the etching time on the enamel hybridization in preventive sealing. In vitro study. Romanian Journal of Oral Reabilitation2011-vol.3,nr.4 pg 84-89 ISSN-2066-7000 baza de date - Index Copernicus, http:// assro.ro/rjor/eng/index.html

29.MACRI S, GONCALVES M, NONAKA T, MAIA DOSSANTOSJ, Scanning Electron Microscopy Evaluation of the Interface of Three Adhesive Systems, Braz Dent J (2002) 13(1):33-38 ISSN 0103-6440.

30.GWINNETT AJ Histologic changes in human enamel following treatment with acidic adhesive conditioning agents Arch Oral Biol 1971; 16:731-738.

31.RETIEF DH Effect of conditioning the enamel surface with phosphoric acid J Dent Res 1973; 52:333-341.

32.SWIFT J. EDWARD, Bonding systems for restorative materials -a comprehensive review, Pediatr. Dent., 20:2,80-84, 1998.

33.SWIFT J. EDWARD, The effect of sealants on dental caries: a review, JADA 1988;9(2):57-60.

34.LICIANE RRS, COSTA, II-SEI WATANABE, MARCELO FAVA, ThreeDimensional Aspects of Etched Enamel in Non-Erupted Deciduous Teeth, Braz Dent J (1998), 9(2):95-100 ISSN 0103-6440.

35.FAVA M, II-SEI WATANABE, FAVA E, Observations on etched enamel in non-erupted deciduous molars: a scanning electron microscopy, Rev Odontol Univ. Sao Paolo v.11, n3, p157-160:1997. 
36.GHIORGHE, CA., GAMEN, AC., TIRCA, T., et al. Laser Therapy Evaluation in Complications of Restorations by Total-Etch Technique, Rev. Chim.(Bucharest), 69, no. 4, 2018, p. 921-925

37.J UMANCA, D., GALUSCAN, A., POPESCU, L., GHIORGHE, A., ANDRIAN, S., SINESCU, C., The purpose of this in comparative study an available sealing materials, Rev Chim. (Bucharest) 67, no.2,2016, p.1
38.DAMIAN, L.R., DUMITRESCU, R., JUMANCA, D, SAVA ROSIANU, R., MATICHESCU, A.M., BALEAN, A., PODARIU, A., STEFANIGA, S.A., GALUSCAN, A., Clinical Study Regarding the Property of Composite Resin, Sealants, using VISTACAM iX, Mat.Plast., 56, no.1, 2019 p.138143.

Manuscript received: 7.04 .2019 